KENYAMANAN TERMAL RUANG TERBUKA HIJAU

DI SEKITAR RUAS JALAN MAGELANG KABUPATEN SLEMAN

Tesis

untuk memenuhi sebagian persyaratan

mencapai derajat Sarjana S-2

Program Studi Geografi

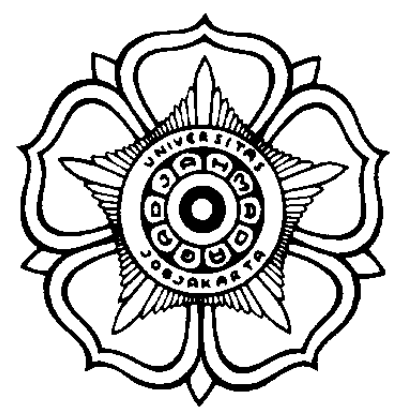

diajukan oleh :

Mukhlison

03/223663/PGE/00385

Kepada

SEKOLAH PASCASARJANA

FAKULTAS GEOGRAFI

UNIVERSITAS GADJAH MADA

YOGYAKARTA

2015 


\title{
KENYAMANAN TERMAL RUANG TERBUKA HIJAU DI SEKITAR RUAS JALAN MAGELANG KABUPATEN SLEMAN
}

\author{
Oleh : \\ Mukhlison
}

\section{INTISARI}

Kepadatan lalu lintas di ruas jalan Magelang Kabupaten Sleman berpotensi meningkatkan suhu udara pada kawasan di sekitarnya akan menyebabkan kondisi yang tidak nyaman. Vegetasi pada ruang terbuka hijau memiliki fungsi untuk mengurangi suhu udara dan sekaligus meningkatkan kenyamanan termal.

Penelitian ini bertujuan untuk mengkaji tipologi dan kondisi vegetasi pada ruang terbuka hijau, mengkaji kenyamanan termal pada berbagai tipe ruang terbuka hijau, serta mengetahui hubungan antara kenyamanan termal dan kondisi ruang terbuka hijau di sekitar ruas Jalan Magelang.

Hasil penelitian menunjukkan bahwa tipe RTH di sekitar ruas jalan Magelang Kabupaten Sleman terdiri atas tipe hutan kota, lahan pekarangan perkotaan, lapangan olah raga, pemakaman, pekarangan dan sempadan sungai. Kondisi vegetasi pada ruang terbuka hijau pada parameter jumlah jenis pohon, kerapatan pohon dan indeks diversitas bervariasi. Kenyamaan termal (THI) pada RTH bervariasi mulai dari yang terendah sebesar 23,79 (nyaman) sampai dengan yang tertinggi sebesar 31,77 (tidak nyaman). Kondisi kenyamanan termal yang termasuk kriteria nyaman hanya terjadi pada pekarangan di Dusun Mlati Dukuh pada pagi hari pukul 06.00 - 08.00 WIB, sementara pada kondisi lainnya menunjukkan kriteria cukup nyaman dan tidak nyaman.

Kata kunci : kenyamanan termal, ruang terbuka hijau, indeks diversitas 


\title{
THERMAL COMFORT ON GREEN OPEN SPACES AROUND THE JALAN MAGELANG, SLEMAN DISTRICT
}

\author{
By : \\ Mukhlison
}

\begin{abstract}
The density of traffic on Jalan Magelang, Sleman district potentially increasing the air temperature in the surrounding area will cause an uncomfortable condition. Vegetation on the green open space has a function to reduce air temperature and simultaneously improve thermal comfort. This study aims to assess the condition of the vegetation on the typology and green open spaces, assessing thermal comfort in various types of open green spaces, as well as determine the relationship between thermal comfort and conditions of open green space around Jalan Magelang.

This study uses a survey to determine the typology of green open spaces, the condition of vegetation on the green open spaces and measure thermal comfort in each of green open space. The measurement results were analyzed descriptively to determine the relationship between the conditions of vegetation on the green open space formed by the thermal comfort.

The results showed that the type of green space around the Jalan Magelang, Sleman district consists of the type of urban forest, urban home gardens, sports fields, cemeteries, yard, and river banks. Vegetation on the green open space in the parameter number of tree species, tree density and diversity index varies. Thermal comfort (THI) at green open space ranged from a low of 23.79 (comfortable) to a high of 31.77 (uncomfortable). Thermal comfort conditions including comfortable criteria only occurs in the yard at Dusun Mlati Dukuh in the morning at 6:00 a.m. to $08: 00 \mathrm{pm}$, while on the other conditions indicate the criteria are quite comfortable and uncomfortable.
\end{abstract}

Keywords: thermal comfort, open green spaces, diversity index 


\section{DAFTAR ISI}

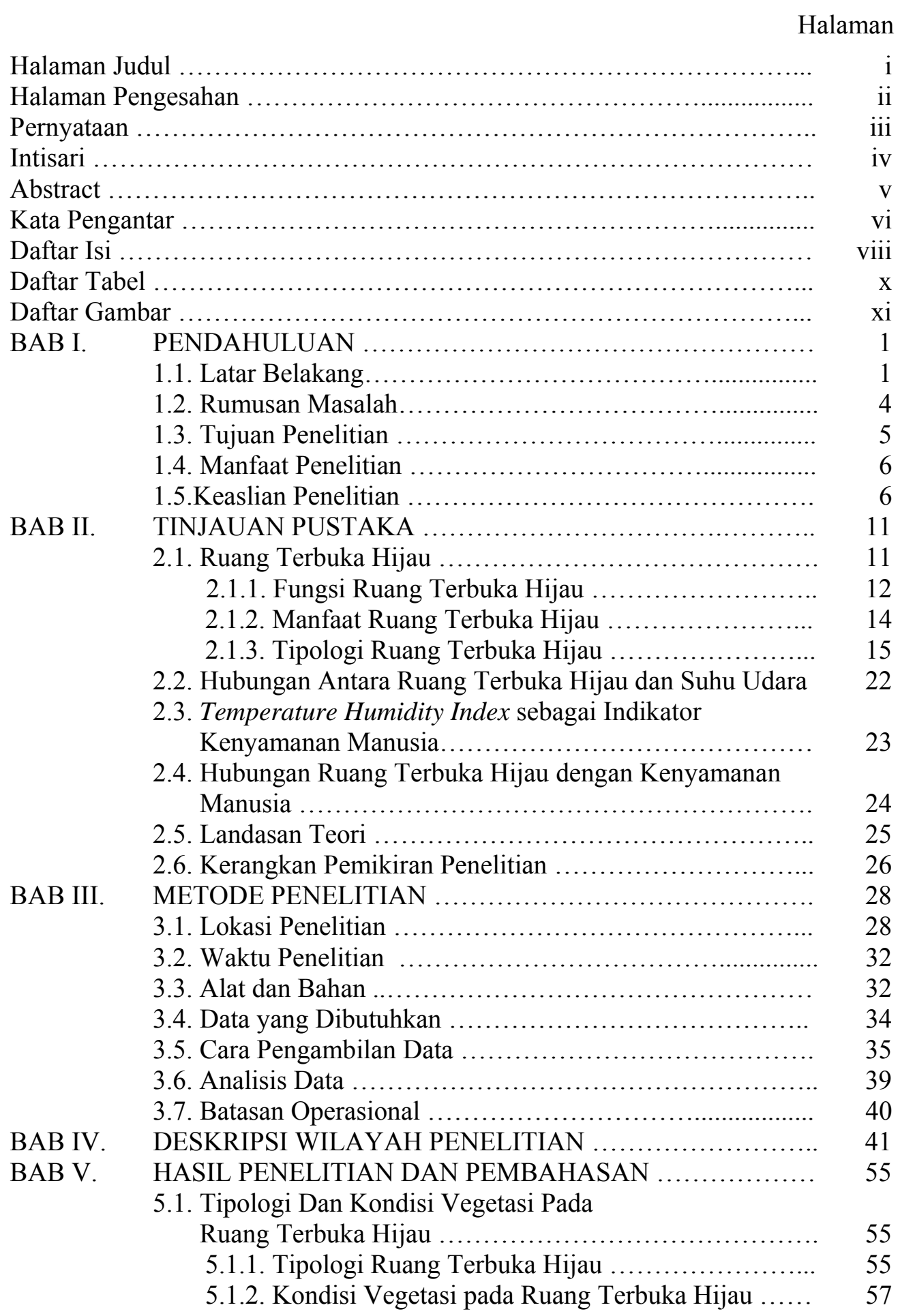


5.2. Suhu Udara, Kelembapan Relatif Udara, dan

Kenyamanan Termal pada Ruang Terbuka Hijau ...

5.3. Hasil Analisis Perbedaan Suhu Udara, Kelembapan

Relatif Udara, dan Kenyamanan Termal pada Berbagai

Ruang Terbuka Hijau

92

5.4. Hubungan antara Kondisi Ruang Terbuka Hijau dengan

Kenyamanan Termal

BAB VI. KESIMPULAN DAN SARAN ........................ 103

6.1. Kesimpulan ...................................... 103

6.2. Saran ................................................ 104

Ringkasan ....................................................... 106

Daftar Pustaka................................................ 134

Lampiran ......................................................... 137 


\section{BAB I \\ PENDAHULUAN}

\subsection{Latar Belakang}

Perkembangan ilmu dan pengetahuan ilmiah, teknologi, dan seni mendorong terciptanya berbagai peralatan yang mempermudah kehidupan manusia. Perkembangan ini di satu sisi memberikan manfaat yang besar bagi manusia, namun di sisi lain kemajuan ilmu dan teknologi juga berdampak pada kerusakan lingkungan. Lingkungan berubah menjadi tidak nyaman bagi aktivitas manusia. Dampak yang cukup nyata dirasakan bagi masyarakat perkotaan adalah peningkatan suhu udara, kebisingan dan berbagai polusi lainnya. Pemanfaatan atas kemajuan ilmu pengetahuan dan teknologi tidak hanya berupa pemenuhan terhadap kebutuhan fisik manusia, tetapi berkembang pada kebutuhan psikis, seperti rasa nyaman yang dihasilkan oleh lingkungan perkotaan yang baik dan sehat. Perkembangan kebutuhan masyarakat perkotaaan terhadap rasa nyaman menyebabkan permintaan terhadap penyediaan pelayanan kota semakin meningkat, misalnya fasilitas rekreasi dan hiburan di perkotaan.

Perkembangan pembangunan daerah berupa peningkatan sarana prasarana wilayah lebih banyak dinikmati oleh masyarakat di kawasan perkotaan. Kawasan perkotaan adalah wilayah yang mempunyai kegiatan utama bukan pertanian dengan susunan fungsi kawasan sebagai tempat permukiman perkotaan, pemusatan dan distribusi pelayanan jasa pemerintahan, pelayanan sosial, dan kegiatan ekonomi (Undang-undang Nomor 26 Tahun 2007 tentang Penataan Ruang). Kawasan perkotaan yang terus berkembang akan memberikan lebih 
banyak peluang kerja bagi masyarakat, sehingga menjadi daya tarik bagi masyarakat pedesaan untuk bekerja di kota. Hal ini menyebabkan perkembangan penduduk kota semakin pesat akibat urbanisasi. Perkembangan penduduk merupakan faktor utama yang menyebabkan peningkatan kebutuhan permukiman serta prasarana dan sarana bagi masyarakat perkotaan. Disamping itu, pertambahan jumlah penduduk juga akan menyebabkan meningkatnya kebutuhan bahan pangan dan energi serta bertambahnya pencemaran lingkungan. Permasalahan lingkungan perkotaan yang diakibatkan oleh peningkatan jumlah dan kepadatan penduduk, serta pertambahan lahan terbangun akan berdampak buruk terhadap lingkungan. Kondisi ini akan bertambah buruk apabila pemerintah daerah yang bersangkutan tidak mempersiapkan strategi perencanaan khusus untuk mengantisipasi segala bentuk perubahan yang terjadi khususnya terhadap pengelolaan lingkungan hidup kawasan perkotaan secara berkesinambungan. Pengelolaan lingkungan perkotaan yang tidak tepat akan menyebabkan terjadinya penurunan kualitas lingkungan hidup. Kondisi demikian menyebabkan terganggunya keseimbangan ekosistem, yang mengakibatkan terjadinya peningkatan suhu udara dan pencemaran udara

Kota Yogyakarta mengalami perkembangan yang pesat dengan kepadatan penduduk yang tinggi. Luas wilayah Kota Yogyakarta yang relatif sempit mendorong perkembangan kota Yogyakarta menuju wilayah di sekitarnya yang secara administratif merupakan wilayah Kabupaten Sleman dan Bantul. Jumlah penduduk dan kepadatan penduduk di wilayah Kota Yogyakarta, Kabupaten 
Sleman dan Kabupaten Bantul berdasarkan Sensus Penduduk tahun 2010 dapat dirinci sebagai berikut.

Tabel 1. Jumlah penduduk dan kepadatan penduduk di Kota Yogyakarta, Kabupaten Sleman dan Kabupaten Bantul berdasarkan Sensus Penduduk tahun 2010

\begin{tabular}{|l|r|r|r|}
\hline Wilayah & $\begin{array}{c}\text { Jumlah } \\
\text { Penduduk } \\
\text { (jiwa) }\end{array}$ & $\begin{array}{c}\text { Luas } \\
\text { Wilayah } \\
\mathbf{( k m}^{2} \text { ) }\end{array}$ & $\begin{array}{c}\text { Kepadatan } \\
\text { Penduduk } \\
\text { (jiwa/km } \mathbf{~} \text { ) }\end{array}$ \\
\hline Kota Yogyakarta & 388.627 & 32,5 & 11.958 \\
\hline Kabupaten Sleman & 1.093 .110 & 574,82 & 1.902 \\
\hline Kabupaten Bantul & 911.503 & 508,85 & 1.794 \\
\hline Daerah Istimewa Yogyakarta & 3.457 .491 & $3.185,80$ & 1.085 \\
\hline
\end{tabular}

Sumber : sp2010.bps.go.id (2013)

Berdasarkan sensus penduduk tahun 2010 diketahui bahwa 66,44\% penduduk Daerah Istimewa Yogyakarta menempati kawasan perkotaan (sp2010.bps.go.id, 2013). Berdasarkan Peraturan Daerah Daerah Istimewa Yogyakarta nomor 2 Tahun 2010 tentang Rencana Tata Ruang Wilayah Daerah Istimewa Yogyakarta tahun 2009-2029 disebutkan bahwa Kawasan Perkotaan Yogyakarta (Aglomerasi Perkotaan Yogyakarta), meliputi Kota Yogyakarta, Kecamatan Depok, sebagian Kecamatan Ngaglik, sebagian Kecamatan Mlati, sebagian Kecamatan Godean, sebagian Kecamatan Gamping, sebagian Kecamatan Ngemplak, sebagian Kecamatan Kasihan, sebagian Kecamatan Sewon, dan sebagian Kecamatan Banguntapan. Ruas jalan Magelang yang menghubungkan Kota Yogyakarta menuju Kota Magelang dan Semarang melintasi sebagian wilayah Kota Yogyakarta dan sebagian Kecamatan Mlati Kabupaten Sleman. Perkembangan transportasi dari Yogyakarta menuju Magelang dan Semarang yang semakin padat juga memicu perkembangan wilayah yang dilalui ruas jalan ini. Perkembangan wilayah di sekitar ruas Jalan Magelang yang melintasi wilayah Kota Yogyakarta 
dan sebagian wilayah Kabupaten Sleman bervariasi akibat pengaruh perkembangan Kota Yogyakarta yang mengarah ke wilayah sekitarnya.

Keberadaan ruang terbuka hijau di wilayah perkotaan sangat penting dalam menjaga kualitas lingkungan. Salah satu fungsi ruang terbuka hijau adalah untuk menjaga suhu dan kelembaban udara yang nyaman bagi manusia, atau lebih dikenal sebagai kenyamanan termal. Kenyamanan yang tinggi dapat diperoleh jika kondisi ruang terbuka hijau di suatu wilayah dalam kondisi yang baik. Untuk itu, penelitian tentang keberadaan ruang terbuka hijau dan kenyamanan termal di sekitar ruas Jalan Magelang perlu dilakukan dalam rangka mengetahui kondisi kualitas lingkungan serta memberikan arahan pengembangan ruang terbuka hijau yang lebih tepat dalam menciptakan kenyamanan termal yang lebih baik.

\subsection{Rumusan Masalah}

Perkembangan fisik Kota Yogyakarta berdampak pada perkembangan sebagian wilayah Kabupaten Sleman yang berbatasan langsung dengan wilayah Kota Yogyakarta. Jalur transportasi darat dari Kota Yogyakarta menuju Semarang melalui ruas jalan Magelang merupakan jalan arteri primer yang memiliki kecenderungan semakin padat dengan meningkatnya kebutuhan transportasi antar daerah. Ruas jalan ini melintasi sebagian wilayah Kota Yogyakarta dan sebagian wilayah Kabupaten Sleman. Keberadaan jalur jalan ini menyebabkan perkembangan ruang terbangun di sekitar jalur jalan semakin meluas dan mengurangi ruang terbuka hijau yang ada selama ini. 
Perkembangan wilayah ini juga dipengaruhi oleh pemenuhan kebutuhan ruang untuk penyediaan fasilitas masyarakat, sehingga perkembangan wilayah ini dapat berlangsung dalam waktu relatif cepat. Hal ini berpotensi menimbulkan penurunan kualitas lingkungan akibat konversi ruang terbuka hijau menjadi ruang terbangun. Berkurangnya ruang terbuka hijau di suatu wilayah akan berdampak pada kenaikan suhu udara dan masyarakat semakin tidak nyaman.

Berdasarkan permasalahan di atas, dapat ditarik rumusan masalah sebagai berikut.

a. Bagaimana tipologi dan sebaran ruang terbuka hijau yang terdapat di sekitar ruas jalan Magelang.

b. Berapa besaran kenyamanan termal pada berbagai tipe ruang terbuka hijau di sekitar ruas jalan Magelang.

c. Bagaimana hubungan antara kenyamanan termal dan kondisi ruang terbuka hijau di sekitar ruas jalan Magelang.

\subsection{Tujuan Penelitian}

Penelitian ini bertujuan untuk :

a. Mengkaji tipologi dan kondisi vegetasi pada ruang terbuka hijau yang terdapat di sekitar ruas jalan Magelang.

b. Mengkaji kenyamanan termal pada berbagai tipe ruang terbuka hijau di sekitar ruas jalan Magelang. 
c. Mengetahui hubungan antara kenyamanan termal dan kondisi ruang terbuka hijau di sekitar ruas jalan Magelang.

\subsection{Manfaat Penelitian}

Penelitian ini bermanfaat untuk :

a. Memberikan sumbangan ilmu pengetahuan tentang hubungan antara kondisi ruang terbuka hijau dengan kenyamanan termal

b. Memberikan dasar pertimbangan untuk arahan pengembangan ruang terbuka hijau untuk meningkatkan kenyamanan termal.

\subsection{Keaslian Penelitian}

Penelitian dengan topik tentang kenyamanan termal maupun indeks kenyamanan telah cukup banyak dilakukan baik di dalam maupun luar negeri. Sejauh pengetahuan penulis, penelitian yang secara khusus mengkaji masalah kenyamanan termal pada berbagai tipe ruang terbuka hijau di ruas Jalan magelang Kabupaten Sleman belum pernah dilakukan. Oleh karena itu, kajian yang peneliti lakukan terjamin keasliannya. Meskipun demikian berbagai penelitian yang ada menjadi masukan berharga bagi peneliti dalam mendukung analisis hasil penelitian.

Penelitian ini mengkaji tentang kondisi penutupan vegetasi dan kenyamanan termal pada berbagai tipe ruang terbuka hijau. Beberapa penelitian lain dengan topik kenyamanan termal pada ruang terbuka hijau dapat dilihat pada Tabel 2 berikut. 
Tabel 2. Hasil penelitian dengan topik terkait dengan topik yang akan dilakukan oleh peneliti

\begin{tabular}{|c|c|c|c|c|c|}
\hline No. & $\begin{array}{c}\text { Peneliti dan } \\
\text { Tahun }\end{array}$ & Lokasi & Judul & Metode & Hasil \\
\hline 1. & $\begin{array}{l}\text { R. Emmanuel } \\
\text { (2004) }\end{array}$ & Sri Lanka & $\begin{array}{l}\text { Thermal comfort } \\
\text { implications of } \\
\text { urbanization in a warm- } \\
\text { humid city: } \\
\text { the Colombo } \\
\text { Metropolitan Region } \\
\text { (CMR), Sri Lanka }\end{array}$ & $\begin{array}{l}\text { Kenyamanan termal diukur } \\
\text { dengan pendekatan Temperature } \\
\text { Humidity Index (THI) dan } \\
\text { Relative Strain Index (RSI) dan } \\
\text { menghubungkannya dengan } \\
\text { perubahan tutupan lahan. } \\
\text { Tutupan lahan dalam bentuk foto } \\
\text { udara time-series (meliputi } \\
\text { bangunan, area beraspal dan jalan, } \\
\text { pohon, area hijau dan badan air) } \\
\text { pada periode pertumbuhan kota } \\
\text { yang lambat hingga } 1977 \text { dan fase } \\
\text { perkotaan yang cepat pada tahun } \\
1978 \text { dan seterusnya. }\end{array}$ & $\begin{array}{l}\text { Kenyamanan termal menurun } \\
\text { terutama pada malam hari sejak } \\
\text { perkembangan kota yang cepat } \\
\text { (dimulai tahun 1977). Hal ini terlihat } \\
\text { terutama di daerah pinggiran kota } \\
\text { dan berkorelasi baik } \\
\text { dengan perubahan tutupan lahan } \\
\text { terbangun. } \\
\text { Tutupan lahan terbangun di daerah } \\
\text { pusat kota lebih berpengaruh pada } \\
\text { ketidaknyamanan termal di pusat } \\
\text { kota daripada di daerah pedesaan. }\end{array}$ \\
\hline 2. & $\begin{array}{l}\text { Imawan } \\
\text { Wahyu } \\
\text { Hidayat } \\
(2010)\end{array}$ & Bogor & $\begin{array}{l}\text { The Ecological Role of } \\
\text { Trees and Their } \\
\text { Interactions in Forming } \\
\text { the Microclimate Amenity } \\
\text { and Environment }\end{array}$ & $\begin{array}{l}\text { Membandingkan suhu dan } \\
\text { kelembaban antara ruang terbuka } \\
\text { yang bebas dari bayangan, dan di } \\
\text { bawah naungan tajuk pohon . } \\
\text { Membuat grid pengamatan } \\
\text { berukuran 50x50 meter yang } \\
\text { terbagi menjadi grid grid yang } \\
\text { lebih kecil berukuran 10x10 } \\
\text { meter, untuk menganalisis suhu } \\
\text { udara dan selanjutnya } \\
\text { dipergunakan untuk membuat } \\
\text { garis isoterm. }\end{array}$ & $\begin{array}{l}\text { Pohon dapat secara signifikan } \\
\text { menurunkan suhu }\left(2,9-7,4^{\circ} \mathrm{C}\right) \text { dan } \\
\text { meningkatkan kelembaban }(0,1-3,9 \\
\%) \text {. } \\
\text { Pohon memiliki peran yang terbatas } \\
\text { dan tidak bisa berdiri sendiri dalam } \\
\text { rangka membentuk iklim mikro } \\
\text { kemudahan dalam lingkungan (THI > } \\
26 \text { ) }\end{array}$ \\
\hline
\end{tabular}

bersambung 
Lanjutan tabel 2

\begin{tabular}{|c|c|c|c|c|c|}
\hline No. & $\begin{array}{c}\text { Peneliti dan } \\
\text { Tahun }\end{array}$ & Lokasi & Judul & Metode & Hasil \\
\hline 3. & $\begin{array}{l}\text { Sobri Effendy, } \\
\text { A. Bey, } \\
\text { A.F.M. Zain , } \\
\text { dan I. Santosa } \\
\text { (2006) }\end{array}$ & $\begin{array}{l}\text { Jakarta, } \\
\text { Bogor, } \\
\text { Tangerang, } \\
\text { Bekasi }\end{array}$ & $\begin{array}{l}\text { Peranan Ruang Terbuka } \\
\text { Hijau dalam } \\
\text { Mengendalikan Suhu } \\
\text { Udara dan Urban Heat } \\
\text { Island Wilayah Jabotabek }\end{array}$ & $\begin{array}{l}\text { Ekstraksi nilai suhu udara dan } \\
\text { NDVI dari data Landsat, berdasar } \\
\text { NDVI dibangkitkan nilai RTH, } \\
\text { lalu estimasi hubungan RTH dan } \\
\text { suhu udara } \\
\text { Uji regresi berganda, analisis } \\
\text { komponen utama (PCA dan rotasi } \\
\text { varimax mengungkap kontribusi } \\
\text { terbesar peubah prediktor } \\
\text { terhadap UHI } \\
\text { Kuantifikasi dampak UHI: THI } \\
\text { dan neraca energi permukaan. }\end{array}$ & $\begin{array}{l}\text { Estimasi hubungan suhu udara dan } \\
\text { RTH dengan R }{ }^{2} \text { adj dan simpangan } \\
\text { baku model (S) menghasilkan } \\
\text { persamaan terpilih non-linier kubik } \\
\text { untuk Jabotabek. Pengurangan RTH } \\
10-50 \% \text { menyebabkan suhu udara } \\
\text { naik 0,2-1,8 }{ }^{\circ} \mathrm{C} \text {. Sebaliknya RTH } \\
\text { bertambah } 10-50 \% \text {, suhu turun } 0,1- \\
0,5^{\circ} \mathrm{C} \text {. } \\
\text { Kepadatan kendaraan kontibutor } \\
\text { dominan UHI di Jakarta, perluasan } \\
\text { urban pemicu UHI Bogor dan } \\
\text { pengurangan RTH penyebab UHI di } \\
\text { Tangerang dan Bekasi. } \\
\text { Peningkatan UHI sebesar } 1,0^{\circ} \mathrm{C} \\
\text { menyebabkan THI naik } 4,9^{\circ} \mathrm{C}\end{array}$ \\
\hline 4. & $\begin{array}{l}\text { Rohman Hadi, } \\
\text { Komang } \\
\text { Arthawa Lila, } \\
\text { dan } \\
\text { I Gusti Alit } \\
\text { Gunadi (2012) }\end{array}$ & $\begin{array}{l}\text { Denpasar, } \\
\text { Bali }\end{array}$ & $\begin{array}{l}\text { Evaluasi Indeks } \\
\text { Kenyamanan Taman Kota } \\
\text { (Lapangan Puputan } \\
\text { Badung I Gusti Ngurah } \\
\text { Made Agung) Denpasar, } \\
\text { Bali }\end{array}$ & $\begin{array}{l}\text { Indeks Kenyamanan diukur } \\
\text { dengan menggunakan Indeks } \\
\text { Kelembaban Thermal (THI). } \\
\text { Lokasi penelitian dibagi dalam } \\
\text { grid dari } 24 \text { plot sampel. Data } \\
\text { persepsi pengunjung kenyamanan } \\
\text { termal ditabulasi, dihitung, dan } \\
\text { diuji dengan menggunakan } \\
\text { metode persentase (\%) dan uji chi } \\
\text { square. }\end{array}$ & $\begin{array}{l}\text { Indeks kenyamanan Termal di } \\
\text { Lapangan Puputan Badung } \\
\text { dikategorikan nyaman. Indeks } \\
\text { kenyamanan termal ini dipengaruhi } \\
\text { oleh iklim mikro, juga dipengaruhi } \\
\text { oleh dominasi pohon di plot } \\
\text { pengamatan. }\end{array}$ \\
\hline
\end{tabular}

bersambung 
Lanjutan tabel 2

\begin{tabular}{|c|c|c|c|c|c|}
\hline No. & $\begin{array}{c}\text { Peneliti dan } \\
\text { Tahun }\end{array}$ & Lokasi & Judul & Metode & Hasil \\
\hline 5. & Tauhid (2008) & Semarang & $\begin{array}{l}\text { Kajian Jarak Jangkau } \\
\text { Efek Vegetasi Pohon } \\
\text { Terhadap Suhu Udara } \\
\text { pada Siang Hari } \\
\text { di Perkotaan (Studi } \\
\text { Kasus: Kawasan Simpang } \\
\text { Lima Kota Semarang) }\end{array}$ & $\begin{array}{l}\text { Penelitian dilaksanakan secara } \\
\text { deskriptif eksploratif dengan } \\
\text { pendekatan kuantitatif. Vegetasi } \\
\text { yang menjadi indikator adalah } \\
\text { pohon Beringin (Ficus benjamina } \\
\text { L.) yang berada di sudut lapangan } \\
\text { bagian Utara. Pengukuran suhu, } \\
\text { RH, kecepatan dan arah angin } \\
\text { serta perawanan dilakukan pada } \\
\text { jam 07.00, 09.00, 11.00, 13.00, } \\
\text { 15.00, 17.00 dan 18.00. }\end{array}$ & $\begin{array}{l}\text { Luas penutupan vegetasi pohon atau } \\
\text { hutan kota } 10 \% \text { belum memadai } \\
\text { sebagai ameliorasi iklim mikro, } \\
\text { khususnya suhu udara. Persentase } \\
\text { luas penutupan vegetasi atau hutan } \\
\text { kota yang mampu menekan kenaikan } \\
\text { suhu udara adalah } 30 \% \text {. } \\
\text { Arah dan kecepatan angin sangat } \\
\text { penting dalam menentukan } \\
\text { efektivitas vegetasi dalam } \\
\text { mengendalikan kenaikan suhu udara. }\end{array}$ \\
\hline 6. & $\begin{array}{l}\text { Ugit Mulgiati } \\
\text { (2010) }\end{array}$ & $\begin{array}{l}\text { Jakarta } \\
\text { Pusat }\end{array}$ & $\begin{array}{l}\text { Pengaruh Penutupan } \\
\text { Vegetasi Terhadap } \\
\text { Kenyamanan Kota }\end{array}$ & $\begin{array}{l}\text { Pengamatan dilakukan pada saat } \\
\text { suhu udara tertinggi, yaitu pada } \\
\text { jam } 11.00-14.00 \text { WIB. Titik } \\
\text { pengamatan dilakukan pada } 49 \\
\text { grid dengan ukuran grid } 500 \mathrm{~m} \mathrm{X} \\
500 \mathrm{~m} \text {. }\end{array}$ & $\begin{array}{l}\text { Penurunan suhu udara sebesar } 0,47^{\circ} \mathrm{C} \\
\text { terjadi bila penambahan luas RTH } \\
\text { sebesar } 1 \% \text { (122.500 m2), dan akan } \\
\text { terjadi peningkatan kelembaban } \\
\text { udara sebesar } 2,05 \% \text {. } \\
\text { Persepsi masyarakat terhadap (1) } \\
\text { perasaan nyaman berada di RTH } \\
\text { jalur jalan, (2) tipe taman yang } \\
\text { diinginkan, dan (3) saran/keinginan } \\
\text { lainnya terhadap RTH terbukti secara } \\
\text { nyata berhubungan langsung dengan } \\
\text { persepsi dan preferensi responden } \\
\text { tentang makna kenyamanan dalam } \\
\text { mendukung aktifitas pada ruang } \\
\text { perkotaan. }\end{array}$ \\
\hline
\end{tabular}

bersambung 
Lanjutan tabel 2

\begin{tabular}{|c|c|c|c|c|c|}
\hline 7. & Peneliti (2014) & $\begin{array}{l}\text { Kota } \\
\text { Yogyakarta } \\
\text { dan } \\
\text { Kabupaten } \\
\text { Sleman }\end{array}$ & $\begin{array}{l}\text { Kenyamanan Termal } \\
\text { Ruang Terbuka Hijau di } \\
\text { Sekitar Ruas Jalan } \\
\text { Magelang Kabupaten } \\
\text { Sleman }\end{array}$ & $\begin{array}{l}\text { Tipologi ruang terbuka hijau } \\
\text { dikaji berdasarkan klasifikasi } \\
\text { menurut Peraturan Menteri Dalam } \\
\text { Negeri No. } 1 \text { tahun } 2007 \text { tentang } \\
\text { Penataan Ruang Terbuka Hijau } \\
\text { Kawasan Perkotaan. Kondisi } \\
\text { vegetasi pada ruang terbuka hijau } \\
\text { diukur dengan cara sensus pada } \\
\text { vegetasi tingkatan hidup pohon } \\
\text { untuk mengetahui kerapatan } \\
\text { pohon dan dominansinya. Di } \\
\text { samping itu juga dibuat diagram } \\
\text { profil untuk mengetahui strutur } \\
\text { vegetai pada ruang terbuka hijau. } \\
\text { Kenyamanan termal diukur } \\
\text { dengan pendekatan Temperature } \\
\text { Humidity Index (THI) } \\
\text { berdasarkan pengukuran suhu dan } \\
\text { kelembaban relatif udara pada } \\
\text { ruang terbuka hijau. }\end{array}$ & $\begin{array}{l}\text { Hasil yang diharapkan dari penelitian } \\
\text { ini adalah tipologi dan kondisi } \\
\text { vegetasi ruang terbuka hijau, } \\
\text { kenyamanan termal pada ruang } \\
\text { terbuka hijau serta hubungan antara } \\
\text { kondisi vegetasi ruang terbuka hijau } \\
\text { dengan kenyamanan termal sehingga } \\
\text { dapat ditentukan tipologi ruang } \\
\text { terbuka hijau yang mampu } \\
\text { memberikan kondisi kenyamanan } \\
\text { termal lebih baik. }\end{array}$ \\
\hline
\end{tabular}




\section{BAB VI \\ KESIMPULAN DAN SARAN}

\subsection{Kesimpulan}

Berdasarkan hasil penelitian dapat ditarik kesimpulan sebagai berikut.

1. Tipe ruang terbuka hijau di sekitar ruas jalan Magelang Kabupaten Sleman terdiri atas tipe hutan kota, lahan pekarangan perkotaan, lapangan olah raga, pemakaman, pekarangan dan sempadan sungai. Kondisi vegetasi pada ruang terbuka hijau pada parameter jumlah jenis pohon, kerapatan pohon dan indeks diversitas bervariasi. Jumlah jenis pohon terendah adalah 1 jenis pohon dijumpai pada pekarangan di Dusun Mlati Dukuh dan sempadan Sungai Bayem, sedangkan ruang terbuka hijau yang memiliki jumlah jenis pohon tertinggi adalah hutan kota Denggung. Kerapatan pohon terendah terdapat di sawah kas Dusun Mulungan Kulon sebesar 26,20 individu/ha, sedangkan kerapatan pohon tertinggi terdapat pada pekarangan di Dusun Mlati Dukuh sebesar 736,54 individu/ha. Indeks diversitas terendah dijumpai pada dua lokasi, yaitu pekarangan di Dusun Mlati Dukuh dan sempadan Sungai Bayem yang keduanya memiliki indeks diversitas 0 karena hanya tersusun oleh satu jenis pohon saja, sedangkan indeks diversitas tertinggi dapat dijumpai di hutan kota Denggung sebesar 2,3 yang termasuk kriteria sedang.

2. Kenyamaan termal (THI) pada ruang terbuka hijau bervariasi mulai dari yang terendah sebesar 23,79 (nyaman) sampai dengan yang tertinggi sebesar 31,77 (tidak nyaman). Kondisi kenyamanan termal yang termasuk kriteria nyaman hanya terjadi pada pekarangan di Dusun Mlati Dukuh pada pagi hari pukul 06.00 - 08.00 WIB, sementara 
pada kondisi lainnya menunjukkan kriteria cukup nyaman dan tidak nyaman. Bahkan pada sawah kas Dusun Mulungan Kulon kondisi kenyamanan termal termasuk kriteria tidak nyaman sejak pagi hari sampai dengan sore hari.

3. Kondisi kenyamanan termal (THI) dipengaruhi oleh kondisi biotis ruang terbuka hijau. Semakin tinggi kerapatan pohon maka kondisi kenyamanan termal akan nyaman atau nilai THI semakin rendah. Untuk meningkatkan kondisi kenyamanan termal dapat dilakukan dengan cara meningkatkan kerapatan pohon dengan penambahan jumlah taaman pada ruang terbuka hijau. Penanaman jenis pohon pada ruang terbuka hijau disesuaikan dengan tujuan pengembangan ruang terbuka hijau. Di samping itu, peningkatan kondisi kenyamanan termal dapat dilakukan dengan penanaman jenis pohon pada kawasan di luar ruang terbuka hijau yang terdapat di sekitar ruas Jalan Magelang, yakni pada areal yang masih dimungkinkan untuk ditanami dengan jenis pohon.

\subsection{Saran}

Berdasarkan penelitian ini dapat diajukan beberapa saran sebagai berikut :

1. Jumlah titik pengukuran suhu udara maupun kelembapan relatif udara perlu ditambah pada setiap lokasi ruang terbuka hijau agar dapat mewakili kondisi yang sebenarnya atau dapat memberi gambaran variasi suhu udara maupun kelembapan yang lebih detail mengingat suhu udara dan kelembapan relatif udara pada ruang terbuka hijau merupakan parameter iklim mikro yang penting.

2. Waktu pengukuran suhu udara dapat direduksi hanya pada siang hari saja, mengingat suhu tertinggi terjadi pada siang hari sementara aktivitas pengguna jalan dan masyarakat di sekitar 
ruas Jalan Magelang cenderung berlangsung pada siang hari, sehingga pengukuran kondisi kenyamanan termal pada siang hari menjadi lebih penting untuk dilakukan. Berdasarkan penelitian ini, kondisi kenyamanan termal yang termasuk kriteria tidak nyaman terjadi pada kisaran waktu pukul 10.00-14.00 WIB. Dengan demikian pengukuran suhu udara dapat dilaksanakan pada kisaran waktu pukul 10.00-14.00 WIB.

3. Pengembangan ruang terbuka hijau untuk meningkatkan kondisi kenyamanan termal dapat ditempuh dengan meningkatkan kerapatan pohon dan menambah jumlah pohon di luar kawasan ruang terbuka hijau, yakni pada areal yang dimungkinkan untuk ditanami dengan jenis pohon. Pemilihan jenis pohon untuk pengembagan ruang terbuka hijau juga harus mempertimbangkan tujuan pembangunan ruang terbuka hijau tersebut, agar manfaat yang dihasilkan oleh ruang terbuka hijau sesuai dengan kondisi yang diharapkan. 


\section{DAFTAR PUSTAKA}

Badan Pusat Statistik. 2013. Sensus Penduduk tahun 2010. http://www.sp2010.bps.go.id. 2 oktober 2013.

Brack CL. 2002. Pollution mitigation and carbon sequestration by an urban forest. Environmental Pollution 116 : 195-200.

Cohen P, Potchter O, Matzarakis A. 2012. Daily and Seasonal Climatic Conditions of Green Urban Open Spaces in the Mediterranean Climate and Their Impact on Human Comfort. J Building and Environment 51:285-295.

Effendy S. 2007. Keterkaitan antara ruang terbuka hijau dengan urban heat island wilayah Jabotabek (disertasi). Bogor : Sekolah Pascasarjana, Intitut Pertanian Bogor.

Effendy S, Bey A, Zain AFM, Santosa I. 2006. Peranan Ruang Terbuka Hijau dalam Mengendalikan Suhu Udara dan Urban Heat Island Wilayah JABOTABEK. J Agromet Indonesia 20(1):23-33.

Emmanuel R. 2005 Thermal Comfort Implications of Urbanization in a Warmhumid City: The Colombo Metropolitan Region (CMR), Sri Lanka. J Building and Evironment 40: 1591- 1601.

Gomez F, Gil L, Jabaloyes J. 2004. Experimental Investigation on the Thermal Comfort in the City: Relationship with the Green Areas, Interaction with the Urban Microclimate. J Building and Environment 39: 1077-1086.

Hadi R, Lila KA, Gunadi IGA. 2012. Evaluasi Indeks Kenyamanan Taman Kota (Lapangan Puputan Badung I Gusti Ngurah Made Agung) Denpasar, Bali. J Agroekoteknologi Tropika 1:34-45.

Hidayat IW. 2010. The Ecological Role of Trees and Their Interactions in Forming the Microclimate Amenity of Environment. J Bumi Lestari 10(2):182-190.

Kakon AN, Nobuo M, Kojima S, Yoko T. 2010. Assessment of Thermal Comfort in Respect to Building Height in a High-Density City in the Tropics. $J$ Engineering and Applied Sciences 3(3):545-551.

Kementerian Pekerjaan Umum Republik Indonesia. 2013. Ruang Terbuka Hijau. http://www.penataanruang.com. 1 Oktober 2013. 
Mulgiati, U. 2010. Pengaruh Penutupan Vegetasi Terhadap Kenyamanan Kota (Tesis). Sekolah Pascasarjana Institut Pertanian Bogor. Bogor.

Oliveira S, Andrade H, Vaz T. 2011. The Cooling Effect of Green Spaces as a Contribution to the Mitigation of Urban Heat: A Case Study in Lisbon. $J$ Building and Enivironment 46:2186-2194.

Pemerintah Daerah Propinsi Daerah Istimewa Yogyakarta. 2010. Peraturan Daerah Propinsi Daerah Istimewa Yogyakarta Nomor 2 Tahun 2010 tentang Rencana Tata Ruang Wilayah Propinsi Daerah Istimewa Yogyakarta tahun 2009-2029.

Pemerintah Republik Indonesia. 1999. Undang-Undang Republik Indonesia Nomor 41 Tahun 1999 tentang Kehutanan.

Pemerintah Republik Indonesia. 2002. Peraturan Pemerintah Republik Indonesia Nomor 63 Tahun 2002 tentang Hutan Kota.

Pemerintah Republik Indonesia. 2007. Peraturan Menteri Dalam Negeri Republik Indonesia Nomor 1 Tahun tentang Penataan Ruang Terbuka Hijau Kawasan Perkotaan.

Pemerintah Republik Indonesia. 2007. Undang-undang Republik Indonesia Nomor 26 Tahun 2007 tentang Penataan Ruang.

Pemerintah Republik Indonesia. 2008. Peraturan Menteri Pekerjaan Umum Republik Indonesia Nomor 5 Tahun 2008 tentang Pedoman Penyediaan Penyelenggaraan dan Pemanfaatan Ruang Terbuka Hijau Kawasan Perkotaan.

Pemerintah Republik Indonesia. 2008. Peraturan Pemerintah Republik Indonesia Nomor 26 Tahun 2008 tentang Rencana Tata Ruang Wilayah Nasional.

Pemerintah Republik Indonesia. 2007. Undang-Undang Nomor 26 Tahun 2007 tentang Penataan Ruang.

Pemerintah Republik Indonesia. 2010. Peraturan Pemerintah Republik Indonesia Nomor 15 Tahun 2010 tentang Penyelenggaraan Penataan Ruang.

Pemerintah Republik Indonesia. 2011. Peraturan Pemerintah Republik Indonesia Nomor 28 Tahun 2011 tentang Pengelolaan Kawasan Suaka Alam dan Kawasan Pelestarian Alam.

Rushayati, SB. 2012. Model Kota Hijau di Kabupaten Bandung Jawa Barat (Disertasi). Sekolah Pascasarjana Institut Pertanian Bogor. Bogor. 
Shahidan MF, Shariff MKM., Jones P, Shalleh E, Abdullah AM. 2010. A Comparison of Mesua ferrea L. And Hurra crepitans L. For Shade Creation and Radiation Modification in Improving Thermal Comfort. $J$ Landscape and Urban Planning 97:168-181.

Tauhid. 2008. Kajian Jarak Jangkau Efek Vegetasi Pohon terhadap Suhu Udara pada Siang Hari di Perkotaan (Tesis). Program Studi Ilmu Lingkungan Program Pascasarjana Universitas Diponegoro. Semarang.

Tulandi D, Promoedyo H, Yanuwiadi RW. 2012. Thermal Comfort Assessment in the Boulevard Area in Manado CBD, North Sulawesi. J Civil and Environmental Engineering 12(2):49-52.

Tursilowati L. 2007. Use of Remote Sensing and GIS to Compute Temperature Humidity Index as Human Comfort Indicator Relate with Land Use-Land Cover Change (LULC) in Surabaya. The 73rd International Symposium on Suistainable Humanosphere :160-166. 